\title{
Benzodithiophene-Based Poly(aryleneethynylene)s: Synthesis, Optical Properties, and Applications in Organic Solar Cells
}

\author{
Shuguang Wen, ${ }^{1}$ Xichang Bao, ${ }^{1}$ Wenfei Shen, ${ }^{1,2}$ Chuantao Gu, ${ }^{1}$ \\ Zhengkun Du, ${ }^{1}$ Liangliang Han, ${ }^{1}$ Dangqiang Zhu, ${ }^{1}$ Renqiang Yang ${ }^{1}$ \\ ${ }^{1}$ CAS Key Laboratory of Bio-based Materials, Qingdao Institute of Bioenergy and Bioprocess Technology, \\ Chinese Academy of Sciences, Qingdao 266101, China \\ ${ }^{2}$ Institute of Hybrid Materials, Laboratory of New Fiber Materials and Modern Textile - The Growing \\ Base for State Key Laboratory, Qingdao University, Qingdao 266071, China \\ Correspondence to: R. Yang (E-mail: yangrq@qibebt.ac.cn)
}

Received 2 September 2013; accepted 21 October 2013; published online 11 November 2013

DOI: 10.1002/pola.26989

ABSTRACT: The synthesis and characterization of building block of ethynylene-substituted benzo[1,2-b:4,5- $\left.b^{\prime}\right]$ dithiophene (BDT), and its application in the construction of poly(aryleneethynylene)s (PAEs) are described in this article. Alkoxy-substituted BDT and thiazolothiazole are selected as the other copolymerized units, and polymers of PEBBDT and PEBTTZ were synthesized by $\mathrm{Pd}$-catalyzed Sonogashira coupling reaction. These polymers showed intense interchain $\pi-\pi$ interaction and deep HOMO levels $(\leq-5.50 \mathrm{eV}$ ). Bulk heterojunction solar cell fabricated using PEBBDT or PEBTTZ as electron donor and $\mathrm{PC}_{61} \mathrm{BM}$ as acceptor display power conversion efficiency of 0.85 and $2.40 \%$, respectively, under the illumination of AM1.5G, $100 \mathrm{~mW}$ $\mathrm{cm}^{-2}$. This study shows good prospect for the application of PAEs-type polymers in organic solar cell. (c) 2013 Wiley Periodicals, Inc. J. Polym. Sci., Part A: Polym. Chem. 2014, 52, 208215

KEYWORDS: bulk-heterojunction; charge transfer; conjugated polymer; heteroatom-containing polymers; organic solar cell; poly(aryleneethynylene)s; structure; property relationships
INTRODUCTION In recent several years, polymer solar cells (PSCs) have attracted much attention in both academia and industry, because of their advantages of flexibility, lightweight, and solution processability. ${ }^{1-4}$ With these efforts, several groups have developed some highly efficient photovoltaic polymers, and power conversion efficiencies (PCEs) of up to $9 \%$ have been achieved in bulk heterojunction (BHJ) cells devices. ${ }^{5-8}$ As well known, the PCE is proportional to the open circuit voltage $\left(V_{\text {oc }}\right)$, short circuit current $\left(U_{\text {sc }}\right)$, and fill factor (FF) of the PSCs. These parameters can be optimized by modifying molecular structures of photovoltaic polymers. ${ }^{9}$ Different strategies have been developed to adjust the relationship of structure-property. For example, the donor-acceptor (D-A) approach is used to construct lowband-gap polymers with tunable energy levels; ${ }^{10}$ mobility of conjugated polymers can be improved by increasing regularity of the backbone units. Such modifications promoted the great development of PSCs.

Poly(aryleneethynylene)s (PAEs) are a fascinating class of conjugated polymers. These polymers have rigid backbones for pronounced interchain interactions and are easily synthe- sized and chemically stable. In recent years, PAEs have attracted much attention in the field of chemical actuators and sensors ${ }^{11}$ but only a few was reported as a PSCs material. $^{12}$ The ethynylene unit in conjugated polymer is characterized as a weak electron-withdrawn group, which is beneficial for lowering the HOMO level and hence increasing $V_{\text {oc }}$ of PSCs. ${ }^{13}$ Furthermore, due to containing the rigid backbone of triple bond, PAE is suspected to have high interchain interactions and ordered arrangement, which favors good charge transport characteristic. Given these considerations, we have developed two BDT-based PAE-type polymers. The BDT unit is connected into the conjugated chain directly through the central benzene ring, which is totally different from the conventional approach (Scheme 1). Compared to the usual benzene unit in poly( $p$-phenylenevinylene)s (PPVs), introduction of the vertical BDT to PAE can expand the dimensionality of $\pi$-conjugated structure, which will contribute to improving $\pi-\pi$ interaction and carrier mobility of the polymer. Thus, ethynylene-substituted BDT monomer (EB, 7) was used as one copolymerized unit. Alkoxy-substituted BDT (8) and thiazolo[5,4-d]thiazole (9) units were used as the other comonomer, and thus, polymers PEBBDT and PEBTTZ 


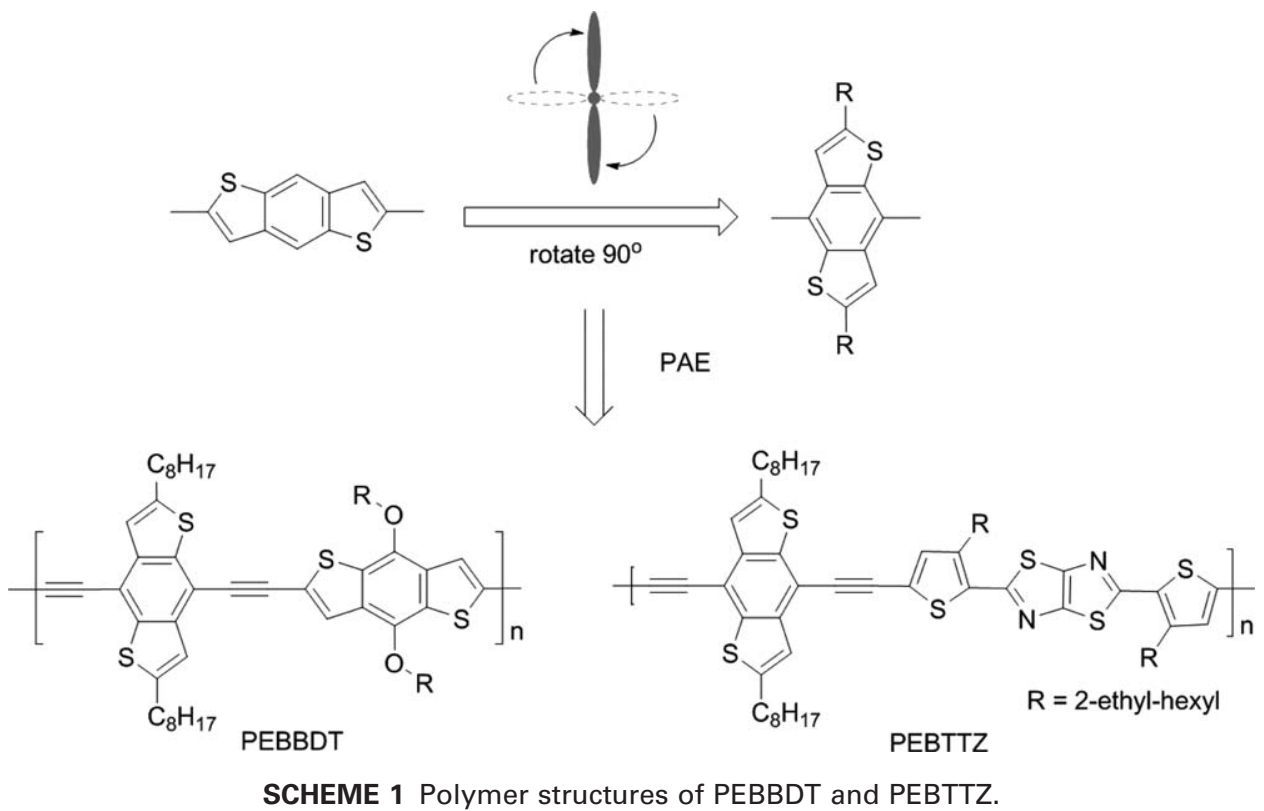

were synthesized by the Sonogashira coupling reaction. They are characterized as ethynylene-containing donor-donor (DD) and donor-acceptor (D-A) type copolymer, respectively. Using PEBBDT and PEBTTZ as electron donor materials and $\mathrm{PC}_{61} \mathrm{BM}$ as the counterpart, solution-processed $\mathrm{BHJ}$ solar cells were fabricated and characterized. The relationship between molecular structure, optical property, nanoscale morphology, and PSCs performance was investigated.

\section{EXPERIMENTAL}

\section{Materials}

All reactions and manipulations were carried out under argon with the use of standard inert atmosphere. Solvents were dried by standard procedures. All column chromatography was performed with the use of silica gel 200-300 mesh. 5-Octylthiophene-3-carboxylic acid (3), ${ }^{14}$ 2,6-dioctyl-4,8-bis (trimethylsilylethynyl)benzo[1,2- $\left.b: 4,5-b^{\prime}\right]$ dithiophene (6), ${ }^{15}$ and polymers were synthesized according to the literature methods. Unless stated otherwise, the other reagents were purchased from commercial sources, and used without further purification.

\section{Instrumentation}

${ }^{1} \mathrm{H}$ NMR and ${ }^{13} \mathrm{C}$ NMR spectra were performed in a Bruker AVANCE-III $600 \mathrm{MHz}$ spectrometer using solutions in $\mathrm{CDCl}_{3}$ and chemical shifts were recorded in ppm units with tetramethylsilane (TMS) as the internal standard. Elemental analyses were carried out using a vario EL cube elemental analyzer. UV-vis spectra were recorded on a Lambda25 spectrophotometer. The electrochemical measurements were carried out under nitrogen on a deoxygenated solution of tetra- $n$-butylammonium hexafluorophosphate $\left(n-\mathrm{Bu}_{4} \mathrm{NPF}_{6}\right.$, $0.1 \mathrm{M}$ ) in acetonitrile with a computer-controlled CHI660C electrochemical workstation, a Pt working electrode, a platinum-wire auxiliary electrode, and an SCE as a pseudore- ference electrode. Potentials were referenced to the ferrocene/ferrocenium $\left(\mathrm{Fc} / \mathrm{Fc}^{+}\right)$couple by using ferrocene as a standard. The HOMO levels of the polymers were determined using the oxidation onset value. Onset potentials are values obtained from the intersection of the two tangents drawn at the rising current and the baseline changing current of the cyclic voltammetry (CV) curves. Differential scanning calorimeter (DSC) and thermal gravimetric analysis (TGA) measurements were performed on STA-409 at a heating rate of $10{ }^{\circ} \mathrm{C} \mathrm{min}^{-1}$. All GPC analyses were made using tetrahydrofuran (THF) as eluant and polystyrene standard as reference. Topographic images of the active layers were obtained through atomic force microscopy (AFM) in tapping mode under ambient conditions using an Agilent 5400 instrument.

\section{Photovoltaic Device Fabrication and Characterization} The PSCs were fabricated with a configuration of ITO/ PEDOT:PSS/polymers: $\mathrm{PC}_{61} \mathrm{BM} / \mathrm{Ca} / \mathrm{Al}$. $\mathrm{A}$ thin layer of PEDOT:PSS [30 nm, poly(3,4-ethylenedioxythiophene):poly(styrenesulfonate)] was spin-cast on precleaned ITO-coated glass from a PEDOT:PSS aqueous solution (Baytron P VP AI 4083 from H. C. Starck) at $4000 \mathrm{rpm}$ and dried subsequently at $150{ }^{\circ} \mathrm{C}$ for $30 \mathrm{~min}$ in air, then the device was transferred into glovebox, where the active layer $(100 \mathrm{~nm})$ of the blend of the polymer and $\mathrm{PC}_{61} \mathrm{BM}$ was spin-coated on the PEDOT:PSS layer. Finally, a Ca $(10 \mathrm{~nm}) / \mathrm{Al}(100 \mathrm{~nm})$ metal top electrode was thermal evaporated onto the active layer under about $2 \times 10^{-4} \mathrm{~Pa}$. The active area of the device was $0.1 \mathrm{~cm}^{2}$ defined by shadow mask. The current density-voltage $(J-V)$ characteristics were measured with a Keithley 2420 source measurement unit under simulated $100 \mathrm{~mW}$ $\mathrm{cm}^{-2}$ (AM 1.5G) irradiation from a Newport solar simulator. Light intensity was calibrated with a standard silicon solar cell. The external quantum efficiencies (EQE) of solar cells were analyzed using a certified Newport incident photon conversion efficiency measurement system. 


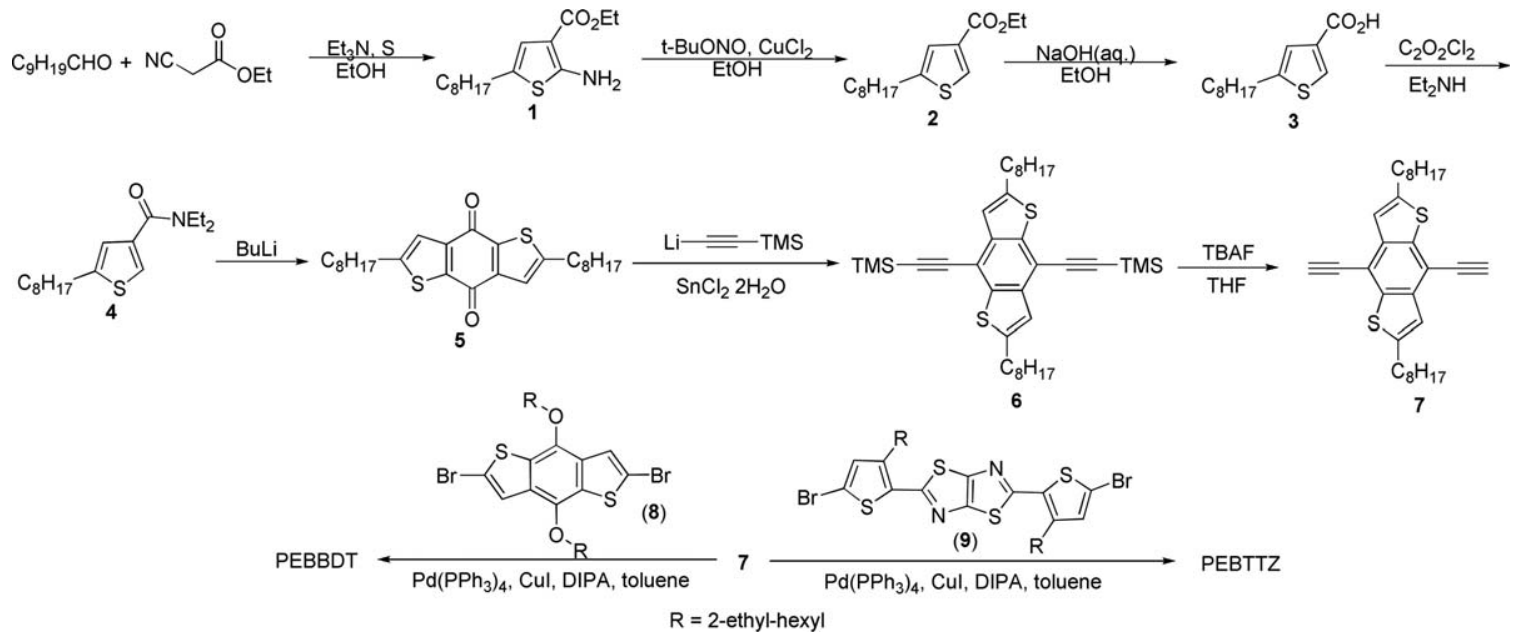

SCHEME 2 Synthetic routes of PEBBDT and PEBTTZ.

\section{Synthesis}

The synthetic routes of the monomers and polymers were shown in Scheme 2. The detailed synthetic processes are described as follows.

\section{Ethyl 2-amino-5-octylthiophene-3-carboxylate (1)}

Decanal (16.07 g, $103 \mathrm{mmol})$, ethyl cyanoacetate $(10.5 \mathrm{~mL}$, $99 \mathrm{mmol})$, and sulfur (3.3 g, $103 \mathrm{mmol}$ ) were dissolved in EtOH $(100 \mathrm{~mL})$. Triethylamine $(20 \mathrm{~mL})$ was added and the reaction was stirred at $60{ }^{\circ} \mathrm{C}$ overnight. The solvent was removed under vacuum and the product was purified by column chromatography on silica, eluting with petroleum ether/ethyl acetate $(10: 1)$. The product was obtained as a yellow oil (28.0 g, 100\%).

${ }^{1} \mathrm{H}$ NMR (600 MHz, CDCl 3 ) $6.54(\mathrm{~s}, 1 \mathrm{H}), 5.72(\mathrm{~s}, 2 \mathrm{H}), 4.18(\mathrm{q}$, $J=7.2 \mathrm{~Hz}, 2 \mathrm{H}), 2.49(\mathrm{t}, J=7.4 \mathrm{~Hz}, 2 \mathrm{H}), 1.49(\mathrm{~m}, 2 \mathrm{H}), 1.27-$ $1.20(\mathrm{~m}, 13 \mathrm{H}), 0.81(\mathrm{t}, J=6.9 \mathrm{~Hz}, 3 \mathrm{H}) ;{ }^{13} \mathrm{C}$ NMR $(150 \mathrm{MHz}$, $\left.\mathrm{CDCl}_{3}\right) \delta$ 164.4. 160.2, 126.0, 120.3, 105.3, 58.5, 30.8, 30.1, 28.7, 28.3, 28.2, 28.0, 21.6, 13.5, 13.1; IR (film) $v_{\max } 3440$, 3334, 2926, 1675, 913, $745 \mathrm{~cm}^{-1}$. Anal. Calcd. for $\mathrm{C}_{15} \mathrm{H}_{25} \mathrm{NO}_{2} \mathrm{~S}: \mathrm{C}, 63.56 ; \mathrm{H}, 8.89 ; \mathrm{N}, 4.94 ; \mathrm{S}, 11.31$. Found: $\mathrm{C}$, 67.61; H, 8.78; N, 5.07; S, 11.18 .

\section{Ethyl 5-octylthiophene-3-carboxylate (2)}

Ethyl 2-amino-5-octylthiophene-3-carboxylate (14.3 g, 50 mmol) was added to a suspension solution of $t$-BuONO (10 $\mathrm{mL}, 75.8 \mathrm{mmol}, 1.5$ equiv) and $\mathrm{CuCl}_{2}$ (7.1 g, $53 \mathrm{mmol}, 1.05$ equiv) in EtOH (100 mL). The reaction mixture was stirred for $0.5 \mathrm{~h}$ then saturated aqueous ammonium chloride (50 $\mathrm{mL}$ ) was added, and the mixture was stirred for a further 15 min. The solvent was removed under vacuum and the residue partitioned between EtOAc and water. The organic layer was dried over $\mathrm{Na}_{2} \mathrm{SO}_{4}$ and concentrated. The residue was purified by column chromatography to give light yellow oil (9.4 g, 70\%).

${ }^{1} \mathrm{H}$ NMR (600 MHz, $\left.\mathrm{CDCl}_{3}\right) 7.80(\mathrm{~d}, J=1.2 \mathrm{~Hz}, 1 \mathrm{H}), 7.11(\mathrm{~d}$, $J=1.0 \mathrm{~Hz}, 1 \mathrm{H}), 4.23(\mathrm{q}, J=7.2 \mathrm{~Hz}, 2 \mathrm{H}), 2.71(\mathrm{t}, J=7.6 \mathrm{~Hz}$, $2 \mathrm{H}), 1.59(\mathrm{~m}, 2 \mathrm{H}), 1.30-1.17(\mathrm{~m}, 13 \mathrm{H}), 0.81(\mathrm{t}, J=7.1 \mathrm{~Hz}$,
$3 \mathrm{H}) ;{ }^{13} \mathrm{C}$ NMR (150 MHz, $\left.\mathrm{CDCl}_{3}\right) \delta 161.9,145.5,132.3$, $129.3,123.4,59.5,30.8,30.4,28.9,28.3,28.2,28.0,21.6$, 13.3, 13.1; IR (film) $v_{\max } 2927,2855,1717,1228,913,743$ $\mathrm{cm}^{-1}$. Anal. Calcd. for $\mathrm{C}_{15} \mathrm{H}_{24} \mathrm{O}_{2} \mathrm{~S}: \mathrm{C}, 67.12 ; \mathrm{H}, 9.01 ; \mathrm{S}, 11.95$. Found: C, 67.26; H, 8.86; S, 11.87 .

\section{5-Octylthiophene-3-carboxylic acid (3)}

A mixture of ester 2 (20.6 g, $71.5 \mathrm{mmol})$ and $\mathrm{NaOH}(5.95 \mathrm{~g}$, $148.7 \mathrm{mmol}$ ) in EtOH (200 mL) was heated to reflux for $3 \mathrm{~h}$. After TLC indicated the absence of starting material, the solvent was removed in vacuo. Water $(100 \mathrm{~mL})$ was added to the residue, and the $\mathrm{pH}$ was adjusted to 1 with $12 \mathrm{M}$ hydrochloric acid. The precipitate was collected by filtration and recrystallized from hexane to yield acid $\mathbf{3}$ as a white solid (13.8 g, 80\%).

${ }^{1} \mathrm{H}$ NMR (600 MHz, $\left.\mathrm{CDCl}_{3}\right) 8.02(\mathrm{~d}, J=1.1 \mathrm{~Hz}, 1 \mathrm{H}), 7.22(\mathrm{~s}$, $1 \mathrm{H}), 2.80(\mathrm{t}, J=7.6 \mathrm{~Hz}, 2 \mathrm{H}), 1.68(\mathrm{~m}, 2 \mathrm{H}), 1.37-1.27(\mathrm{~m}$, $10 \mathrm{H}), 0.81(\mathrm{t}, J=7.0 \mathrm{~Hz}, 3 \mathrm{H}) ;{ }^{13} \mathrm{C} \mathrm{NMR}\left(150 \mathrm{MHz} \mathrm{CDCl}_{3}\right) \delta$ 168.3, 147.0, 132.6, 132.3, 124.5, 31.8, 31.4, 29.9, 29.3, 29.2, 29.0, 22.7, 14.1; IR (film) $v_{\max } 2926,2853,1663,1468,911$, $732 \mathrm{~cm}^{-1}$. Anal. Calcd. for $\mathrm{C}_{13} \mathrm{H}_{20} \mathrm{O}_{2} \mathrm{~S}$ : C, 64.96; H, 8.39; S, 13.34. Found: C, 65.15; H, 8.19; S, 13.56 .

\section{N,N-Diethyl-5-octylthiophene-3-carboxamide (4)}

5-Octylthiophene-3-carboxylic acid (5.87 g, $244 \mathrm{mmol}$ ) and $50 \mathrm{~mL}$ of methylene chloride were put into a 150 -mL flask. The mixture was cooled by ice-water bath, and then oxalyl chloride ( $4.3 \mathrm{~mL}, 489 \mathrm{mmol}$ ) was added in one portion. The reactant was stirred overnight at ambient temperature, and a clear solution was obtained. After removing the solvent and unreacted oxalyl chloride by rotary evaporation, the corresponding thiophene-3-carbonyl chloride was obtained. It was dissolved into $50 \mathrm{~mL}$ of methylene chloride and used for the next step.

In a $150-\mathrm{mL}$ flask in ice-water bath, diethylamine $(5.1 \mathrm{~mL}$, $489 \mathrm{mmol}$ ) and $50 \mathrm{~mL}$ of methylene chloride were mixed, and the solution of thiophene-3-carbonyl chloride was added into the flask slowly. After all of the solution was added, the 
ice bath was removed, and the reactant was stirred at ambient temperature for $30 \mathrm{~min}$. Then, the reactant was washed by water several times, and the organic layer was dried over anhydrous $\mathrm{Na}_{2} \mathrm{SO}_{4}$. After removing solvent, the crude product was purified by column chromatography to give pale yellow oil $(6.5 \mathrm{~g}, 90 \%)$.

${ }^{1} \mathrm{H}$ NMR (CDCl $\left.3,600 \mathrm{MHz}\right): 7.22(\mathrm{~d}, J=1.4 \mathrm{~Hz}, 1 \mathrm{H}), 6.85(\mathrm{~d}$, $J=1.0 \mathrm{~Hz}, 1 \mathrm{H}), 3.43(\mathrm{br}, 4 \mathrm{H}), 2.78(\mathrm{t}, J=7.7 \mathrm{~Hz}, 2 \mathrm{H}), 1.66$ $(\mathrm{m}, 2 \mathrm{H}), 1.37-1.19(\mathrm{~m}, 16 \mathrm{H}), 0.88(\mathrm{t}, J=7.0 \mathrm{~Hz}, 3 \mathrm{H}) ;{ }^{13} \mathrm{C}$ NMR (150 MHz, $\left.\mathrm{CDCl}_{3}\right) \delta 166.9,146.3,137.0,123.8,122.4$, $31.8,31.5,29.9,29.3,29.2,29.0,22.7,14.1$; IR (film) $v_{\max }$ 2928, 2855, 1628, 1463, 913, $743 \mathrm{~cm}^{-1}$. Anal. Calcd. for $\mathrm{C}_{17} \mathrm{H}_{29}$ NOS: C, 69.10; $\mathrm{H}, 9.89 ; \mathrm{N}, 4.74 ; \mathrm{S}, 10.85$. Found: C, 69.19; H, 10.02; N, 4.85; S, 10.74.

\section{2,6-Dioctyl-4,8-dihydrobenzo[1,2-b:4,5-b']dithiophen-4,8- dione (5)}

Compound 4 (2.95 g, $10.0 \mathrm{mmol}$ ) was put into a welldried flask with $100 \mathrm{~mL}$ of THF under an inert atmosphere. The solution was cooled down by an ice-water bath, and $7.0 \mathrm{~mL}$ of $n$-butyllithium (11.2 mmol, $1.6 \mathrm{M})$ was added into the flask dropwise. Then, the reactant was stirred at ambient temperature for $30 \mathrm{~min}$. The reactant was poured into ice water and stirred for several hours. The mixture was filtrated, and the yellow precipitate was washed by water, methanol, and hexane successively. The product was obtained as a yellow solid (1.6 g, $72 \%)$.

${ }^{1} \mathrm{H}$ NMR $\left(\mathrm{CDCl}_{3}, 600 \mathrm{MHz}\right): 7.30(\mathrm{~s}, 2 \mathrm{H}), 2.89(\mathrm{t}, J=1.6 \mathrm{~Hz}$, $4 \mathrm{H}), 1.74(\mathrm{~m}, 4 \mathrm{H}), 1.41-1.27(\mathrm{~m}, 20 \mathrm{H}), 0.90(\mathrm{t}, J=7.0 \mathrm{~Hz}$, $6 \mathrm{H}) ;{ }^{13} \mathrm{C} \mathrm{NMR}\left(150 \mathrm{MHz}, \mathrm{CDCl}_{3}\right) \delta 174.6,155.7,143.1$, $141.9,123.6,31.8,31.2,30.6,29.2,29.1,29.0,22.6,14.1$; IR (film) $v_{\max } 2920,2853,1645,1452,908,732 \mathrm{~cm}^{-1}$. Anal. Calcd. for $\mathrm{C}_{26} \mathrm{H}_{36} \mathrm{O}_{2} \mathrm{~S}_{2}$ : C, 70.22; H, 8.16; S, 14.42. Found: C, 70.43; H, 8.09; S, 14.39.

\section{2,6-Dioctyl-4,8-bis(trimethylsilylethynyl)-benzo[1,2-b:4,5- $b^{\prime}$ ]dithiophene (6)}

Under an atmosphere of argon, $n$-butyllithium (7.57 mL, 1.6 $\mathrm{M}$ in hexane, $12 \mathrm{mmol}$ ) was added dropwise to a solution of (trimethylsilyl)acetylene (1.67 mL, $12 \mathrm{mmol}$ ) in THF (15 $\mathrm{mL}$ ) at $0{ }^{\circ} \mathrm{C}$. The mixture was then kept at $0{ }^{\circ} \mathrm{C}$ for another $40 \mathrm{~min}$ before it was transferred to a solution of quinone $\mathbf{5}$ (2.15 g, $4.8 \mathrm{mmol})$ in THF $(30 \mathrm{~mL})$ at $0{ }^{\circ} \mathrm{C}$. The mixture was warmed to room temperature and stirred overnight. The reaction was quenched with $9 \mathrm{~mL}$ of $10 \% \mathrm{HCl}$ and then subjected to a $\mathrm{CHCl}_{3} / \mathrm{H}_{2} \mathrm{O}$ workup. The solvent was removed and the crude residue was dissolved in $48 \mathrm{~mL}$ of acetone. Then a solution of tin (II) chloride dihydrate (2.46 g, 10.9 $\mathrm{mmol}$ ) in $50 \%$ of acetic acid $(48 \mathrm{~mL})$ was added dropwise. This mixture was stirred at room temperature for another $24 \mathrm{~h}$, and the resulting solid product was filtered. The solid was then dissolved in $\mathrm{CHCl}_{3}$, washed with water and sodium bicarbonate solution, and then dried by $\mathrm{Na}_{2} \mathrm{SO}_{4}$. The $\mathrm{CHCl}_{3}$ was removed in vacuo and the residue was purified by column chromatography on silica to give the product $\mathbf{6}$ as a white solid (0.92 g, 32\%).
${ }^{1} \mathrm{H}$ NMR (600 MHz, $\left.\mathrm{CDCl}_{3}\right) 7.23(\mathrm{~s}, 2 \mathrm{H}), 2.96(\mathrm{t}, J=7.6 \mathrm{~Hz}$, $4 \mathrm{H}), 1.81(\mathrm{~m}, 4 \mathrm{H}), 1.46-1.28(\mathrm{~m}, 20 \mathrm{H}), 0.91(\mathrm{t}, J=7.0,6 \mathrm{H})$, 0.39 (s, 18H); ${ }^{13} \mathrm{C}$ NMR (150 $\left.\mathrm{MHz} \mathrm{CDCl}_{3}\right)$ 148.4, 139.9, 138.2, 119.6, 110.4, 104.1, 101.1, 31.9, 31.3, 31.2, 31.1, 29.4, 29.2, 22.3, 14.1, 0.1; IR (film) $v_{\max }$ 2952, 2928, 2151, 1249, 842, $758 \mathrm{~cm}^{-1}$. Anal. Calcd. for $\mathrm{C}_{36} \mathrm{H}_{54} \mathrm{~S}_{2} \mathrm{Si}_{2}: \mathrm{C}, 71.22 ; \mathrm{H}$, 8.97; S, 10.56. Found: C, 71.06; H, 8.73; S, 10.78 .

\section{2,6-Dioctyl-4,8-diethynyl-benzo[1,2-b:4,5-b']dithiophene (7)} Compound 6 (143 mg, $0.23 \mathrm{mmol}$ ) was dissolved in dry THF ( $3 \mathrm{~mL})$. The solution was cooled to $0{ }^{\circ} \mathrm{C}$ and $\mathrm{Bu}_{4} \mathrm{NF}(142 \mu \mathrm{L}$, $1 \mathrm{M}$ in THF, $0.14 \mathrm{mmol}$ ) was added dropwise. After $30 \mathrm{~min}$, the reaction was quenched with water and extracted with $\mathrm{CHCl}_{3}$. The organic phase was washed with saturated brine, dried with $\mathrm{Na}_{2} \mathrm{SO}_{4}$ and concentrated. The residue was purified by column chromatography with hexane to give the compound 7 as white solid (98 mg, 81\%).

${ }^{1} \mathrm{H}$ NMR (600 MHz, CDCl 3 ) $7.28(\mathrm{~s}, 2 \mathrm{H}), 3.80(\mathrm{~s}, 2 \mathrm{H}), 2.96(\mathrm{t}$, $J=7.6 \mathrm{~Hz}, 4 \mathrm{H}), 1.81(\mathrm{~m}, 4 \mathrm{H}), 1.46-1.29(\mathrm{~m}, 20 \mathrm{H}), 0.91(\mathrm{t}$, $J=7.0 \mathrm{~Hz}, 6 \mathrm{H}) ;{ }^{13} \mathrm{C}$ NMR $\left(150 \mathrm{MHz}, \mathrm{CDCl}_{3}\right) 148.7,140.0$, 138.7, 119.5, 109.6, 86.0, 80.0, 31.9, 31.2, 31.0, 29.3, 29.2, 29.1, 22.3, 14.1; IR (film) $v_{\max } 3289,2924,2848,2102$, 1172, $665 \mathrm{~cm}^{-1}$. Anal. Calcd. for $\mathrm{C}_{30} \mathrm{H}_{38} \mathrm{~S}_{2}$ : C, 77.98; $\mathrm{H}, 8.28$; S, 13.86. Found: C, 77.86; H, 8.30; S, 13.67 .

\section{Synthesis of Polymer PEBBDT}

A mixture of diyne monomer 7 (73.9 mg, $0.160 \mathrm{mmol})$, dibromo monomer 8 (96.6 mg, $0.160 \mathrm{mmol}, 1.0$ equiv), $\mathrm{Pd}\left(\mathrm{PPh}_{3}\right)_{4}(9.2 \mathrm{mg}, 0.008 \mathrm{mmol}, 0.05$ equiv), and $\mathrm{CuI}(2.4$ $\mathrm{mg}, 0.013 \mathrm{mmol}, 0.08$ equiv) are placed in a Schlenk flask equipped with a magnetic stirrer. Contents are evacuated and back-filled with argon five times. Degassed toluene (3 $\mathrm{mL}$ ) and diisopropylamine (1 $\mathrm{mL}$ ) are introduced, and after five more quick vacuum/back-fill cycles, the resulting mixture is stirred at room temperature for $30 \mathrm{~min}$, followed by $48 \mathrm{~h}$ at $65{ }^{\circ} \mathrm{C}$ and $24 \mathrm{~h}$ at $75{ }^{\circ} \mathrm{C}$. After cooling to room temperature, contents are precipitated in $\mathrm{MeOH}$, and isolated by centrifugation. Then, the crude polymer is extracted with $\mathrm{MeOH}$, acetone, hexane, and $\mathrm{CHCl}_{3}$ in a Soxhlet extractor successively. The fraction from chloroform was concentrated under reduced pressure and precipitated into methanol to give the polymer as a red solid (108 $\mathrm{mg}, 74 \%$ ). GPC: $M_{\mathrm{n}}=18.5 \mathrm{~K} ; M_{\mathrm{w}} / M_{\mathrm{n}}=1.5$.

${ }^{1} \mathrm{H}$ NMR (600 MHz, $\left.\mathrm{CDCl}_{3}\right), \delta(\mathrm{ppm}): 7.76-7.36(\mathrm{~m}, 4 \mathrm{H})$, 4.28-4.19 (m, 4H), 3.03 (br, 4H), 1.88-0.92 (m, 60H). Anal. Calcd. for $\mathrm{C}_{56} \mathrm{H}_{72} \mathrm{O}_{2} \mathrm{~S}_{4}$ : C, 74.29; $\mathrm{H}, 8.02 ; \mathrm{S}, 14.17$. Found: C, 74.13; H, 8.32; S, 14.28 .

\section{Synthesis of polymer PEBTTZ}

A mixture of diyne monomer 7 (92.4 mg, $0.20 \mathrm{mmol}$ ), dibromo monomer 9 (138.0 mg, $0.20 \mathrm{mmol}, 1.0$ equiv), $\mathrm{Pd}\left(\mathrm{PPh}_{3}\right)_{4}(11.5 \mathrm{mg}, 0.010 \mathrm{mmol}, 0.05$ equiv), and $\mathrm{CuI}$ (3.0 $\mathrm{mg}, 0.016 \mathrm{mmol}, 0.08$ equiv) are placed in a Schlenk flask equipped with a magnetic stirrer. Contents are evacuated and back-filled with argon five times. Degassed toluene (4.2 $\mathrm{mL})$ and diisopropylamine $(1.4 \mathrm{~mL})$ are introduced, and after five more quick vacuum/back-fill cycles, the resulting 
TABLE 1 Molecular Weights, Polydispersity Index, and Thermal Properties of Polymers

\begin{tabular}{lcccc}
\hline Polymers & $M_{\mathrm{w}}(\mathrm{K})$ & $M_{\mathrm{n}}(\mathrm{K})$ & $\mathrm{PDI}$ & $T_{\mathrm{d}}\left({ }^{\circ} \mathrm{C}\right)^{\mathrm{a}}$ \\
PEBBDT & 27.7 & 18.5 & 1.5 & 359 \\
PEBTTZ & 19.7 & 8.6 & 2.3 & 393
\end{tabular}

a The $5 \%$ weight-loss temperatures under inert atmosphere.

mixture is stirred at room temperature for $30 \mathrm{~min}$, followed by $48 \mathrm{~h}$ at $65{ }^{\circ} \mathrm{C}$ and $24 \mathrm{~h}$ at $75{ }^{\circ} \mathrm{C}$. After cooling to room temperature, contents are precipitated in $\mathrm{MeOH}$, and isolated by centrifugation. Then the crude polymer is extracted with $\mathrm{MeOH}$, acetone, hexane, and $\mathrm{CHCl}_{3}$ in a Soxhlet extractor successively. The fraction from chloroform was concentrated under reduced pressure and precipitated into methanol to give the polymer as a red solid (53 mg, 26\%). GPC: $M_{\mathrm{n}}=8.6$ $\mathrm{K} ; M_{\mathrm{w}} / M_{\mathrm{n}}=2.3$.

${ }^{1} \mathrm{H}$ NMR (600 MHz, $\left.\mathrm{CDCl}_{3}\right), \delta(\mathrm{ppm}):$ 7.27-6.94 (m, 4H), 3.03-2.87 (m, 8H), $1.86(\mathrm{~m}, 2 \mathrm{H}), 1.57-1.28$ (m, 40H), 0.990.89 (m, 18H). Anal. Calcd. for $\mathrm{C}_{58} \mathrm{H}_{72} \mathrm{~N}_{2} \mathrm{~S}_{6}$ : C, 70.39; $\mathrm{H}, 7.33$; N, 2.83; S, 19.44. Found: C, 70.52; H, 7.17; N, 2.72; S, 19.58.

\section{RESULTS AND DISCUSSION}

\section{Synthesis and Structural Characterization}

The polymers PEBBDT and PEBTTZ were synthesized by Pd/ Cu-catalyzed Sonogashira coupling copolymerization of alkyne $\mathbf{7}$ with dibromide compounds $\mathbf{8}$ and $\mathbf{9}$, respectively, in toluene. The comonomer $\mathbf{7}$ was synthesized from thiophene-3-carboxylic acid 3, similar to the synthesis of common BDT compound. ${ }^{15}$ The 2-alkyl substituted thiophene unit was obtained by a three-component reaction manner of aldehyde, sulfur, and cyanoacetate to produce 2-amino thiophene $1{ }^{14}$ Then through the reaction of deamination and hydrolysis the compound $\mathbf{3}$ was obtained in good yield. PEBBDT was readily soluble in organic solvents [chloroform, THF, chlorobenzene (CB), etc.] at room temperature, whereas PEBTTZ was less soluble in these solvents.

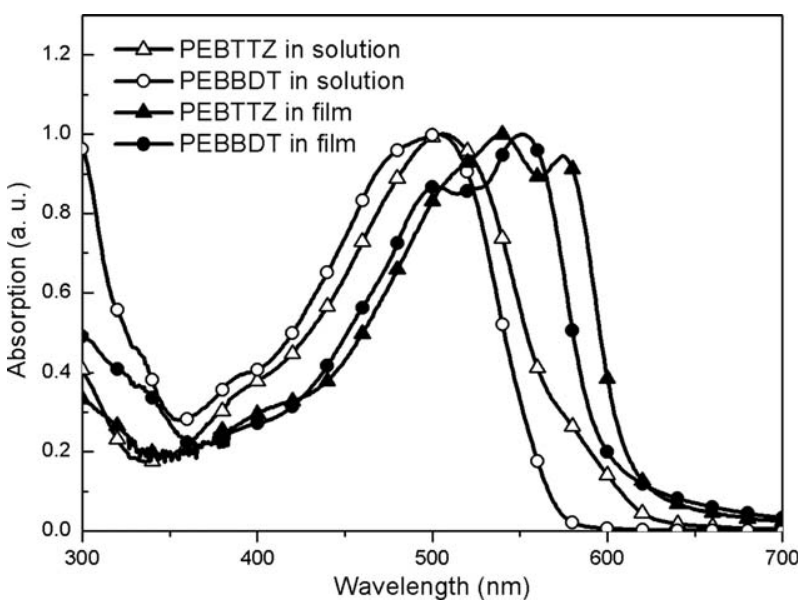

FIGURE 1 Absorption spectra of PEBBDT and PEBTTZ in dilute chloroform solutions and as thin films.
TABLE 2 Optical Properties and Energy Levels of Polymers PEBBDT and PEBTTZ

\begin{tabular}{lcccccc}
\hline & \multicolumn{2}{c}{$\lambda_{\text {max }}{ }^{a}(\mathrm{~nm})$} & & & \\
\cline { 2 - 3 } Polymers & Solution & Film & & $E_{\mathrm{g}}{ }^{\text {opt b }}$ & $\begin{array}{c}\mathrm{HOMO}^{\mathrm{c}} \\
(\mathrm{eV})\end{array}$ & $\begin{array}{c}\mathrm{LUMO}^{\mathrm{d}} \\
(\mathrm{eV})\end{array}$ \\
PEBBDT & 503 & 503,551 & 2.08 & -5.57 & -3.49 \\
PEBTTZ & 506 & 539,574 & 2.04 & -5.50 & -3.46
\end{tabular}

a Absorption maxima.

b Optical band gap estimated from the onset of absorption spectra in solid film.

${ }^{\mathrm{c}}$ Determined from the onset oxidation based on the reference energy level (ref. 16).

${ }^{\mathrm{d}}$ Calculated by the equation LUMO $=\mathrm{HOMO}+E_{\mathrm{g}}{ }^{\mathrm{opt}}(\mathrm{eV})$.

The molecular weights of the polymers were estimated using gel permeation chromatography measured in THF relative to polystyrene standards. The results are summarized in Table 1. PEBTTZ was obtained with lower molecular weights than PEBBDT, which may be caused by the poor solubility of PEBTTZ in the reaction. Thermal stability of the polymers was investigated with TGA under a nitrogen atmosphere. The decomposition temperatures $\left(T_{\mathrm{d}}\right)$ of PEBBDT and PEBTTZ are 359 and $393{ }^{\circ} \mathrm{C}$, respectively (Table 1 , Supporting Information Fig. 1S), demonstrating their sufficiently high thermal stability for applications in PSCs. DSC measurement of the polymers showed no apparent phase transition up to $250{ }^{\circ} \mathrm{C}$, indicating that the polymers tended to be amorphous.

\section{Optical Properties}

The photophysical characteristics of the polymers were investigated by ultraviolet-visible (UV-vis) absorption spectroscopy in dilute chloroform solutions and as spincoated films on quartz substrates, as shown in Figure 1. Both of the polymers PEBBDT and PEBTTZ show similar absorption band with maximum peak at 503 and $506 \mathrm{~nm}$ in solution, respectively (Table 2). The thin film absorption spectrum of PEBBDT has two peaks at 503 and $551 \mathrm{~nm}$, resulting in an absorption edge optical band gap $\left(E_{\mathrm{g}}{ }^{\text {opt }}\right)$ of $2.08 \mathrm{eV}$. Similarly, PEBTTZ shows a maximum absorption at $539 \mathrm{~nm}$ and a shoulder at $574 \mathrm{~nm}$. The optical band gap of $2.04 \mathrm{eV}$ is slightly reduced compared to PEBBDT. Compared with the absorption spectra of polymers in solution, clear shoulder peaks are formed in the solid film spectra, which indicate that there have strong $\pi-\pi$ stacking interchain interactions or aggregation in PEBBDT and PEBTTZ solid films.

\section{Electrochemical Properties}

The electrochemical CV (Fig. 2) of PEBBDT and PEBTTZ was performed in acetonitrile at a potential scan rate of $50 \mathrm{mV}$ $\mathrm{s}^{-1}$ for determining the HOMO energy levels of the polymer films. And a standard ferrocene/ferrocenium $\left(\mathrm{Fc} / \mathrm{Fc}^{+}\right)$redox system was used as the internal standard. The results are summarized in Table 2. The CV curves of PEBBDT and PEBTTZ films show the oxidation peaks with the onset oxidation potentials $\left(\varphi_{\text {ox }}\right)$ of 1.16 and $1.09 \mathrm{~V}$ versus SCE, corresponding to the HOMO energy level of -5.57 and $-5.50 \mathrm{eV}$, 


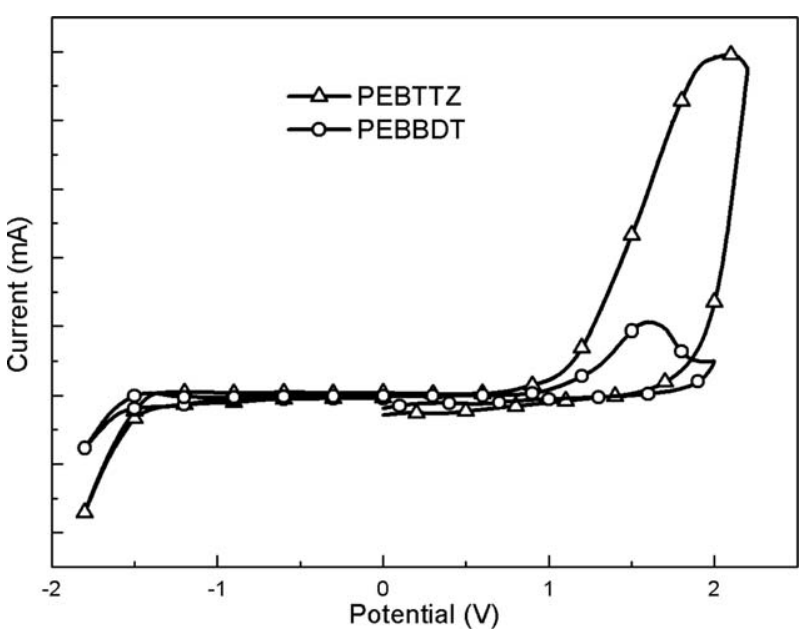

FIGURE 2 Cyclic voltammograms of PEBBDT and PEBTTZ films on Pt electrode in a $0.1 \mathrm{~mol} \mathrm{~L}{ }^{-1} n-\mathrm{Bu}_{4} \mathrm{NPF}_{6}$ acetonitrile solution at a sweep rate of $50 \mathrm{mV} \mathrm{s}^{-1}$.

respectively. The low-lying HOMO level is attributed to the incorporation of weak electron-withdrawing triple bonds in the conjugated polymer main chains. Note that the HOMO energy level is estimated using the following relation: HOMO $=-e\left(E^{\text {ox }}\right.$ (onset $)-E^{1 / 2}$ (ferrocene $\left.)+4.8\right)(\mathrm{eV})$, where the unit of $E^{\text {ox }}$ (onset) is $\mathrm{V}$ (vs. SCE). ${ }^{16}$ The relatively deep HOMO levels of both polymers provide better air stability in ambient conditions and higher $V_{\text {oc }}$ of the PSCs because the $V_{\text {oc }}$ is usually proportional to the difference between the LUMO level of the acceptor and the HOMO level of the donor. $^{17}$ The LUMO energy levels of PEBBDT and PEBTTZ were determined to be -3.49 and $-3.46 \mathrm{eV}$, respectively, which guarantee the charge separation between the donor and acceptor (Table 2).

\section{Photovoltaic Properties}

In order to investigate the potential applications of the copolymers in solar cells, the bulk heterojunction PSCs were

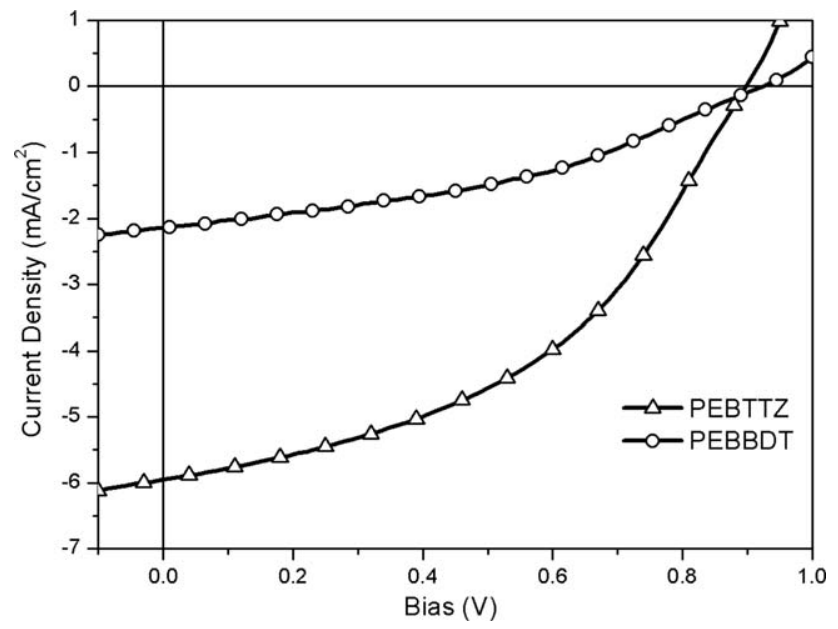

FIGURE 3 Typical $J-V$ curves of the PSCs based on polymers: $\mathrm{PC}_{61} \mathrm{BM}(1: 1)$ under $\mathrm{AM} 1.5 \mathrm{G}$ illumination $\left(100 \mathrm{~mW} \mathrm{~cm}^{-2}\right)$.
TABLE 3 Photovoltaic Properties of PSCs Based on Polymers: $\mathrm{PC}_{61} \mathrm{BM}=1: 1$

\begin{tabular}{|c|c|c|c|c|c|}
\hline Polymer $^{\mathrm{a}}$ & Treatment & $\begin{array}{l}V_{\mathrm{oc}} \\
(\mathrm{V})\end{array}$ & $\begin{array}{c}J_{\mathrm{sc}}(\mathrm{mA} \\
\left.\mathrm{cm}^{-2}\right)\end{array}$ & $\begin{array}{l}\mathrm{FF} \\
(\%)\end{array}$ & $\begin{array}{l}\text { PCE } \\
(\%)\end{array}$ \\
\hline \multirow[t]{2}{*}{ PEBBDT } & $\begin{array}{l}\text { Annealed } \\
\text { at } 80^{\circ} \mathrm{C}\end{array}$ & 0.92 & 2.38 & 39.0 & 0.85 \\
\hline & As cast & 0.87 & 1.51 & 33.1 & 0.43 \\
\hline \multirow[t]{2}{*}{ PEBTTZ } & $\begin{array}{l}\text { Annealed } \\
\text { at } 80^{\circ} \mathrm{C}\end{array}$ & 0.83 & 3.83 & 40.0 & 1.59 \\
\hline & As cast & 0.90 & 5.95 & 45.0 & 2.40 \\
\hline
\end{tabular}

a $10 \mathrm{mg} \mathrm{mL}^{-1}$ of polymer in $\mathrm{CB}$ solution.

fabricated with device structure of ITO/PEDOT:PSS/polymers: $\mathrm{PC}_{61} \mathrm{BM} / \mathrm{Ca} / \mathrm{Al}$. Both PEBBDT/ $\mathrm{PC}_{61} \mathrm{BM}$ and PEBTTZ/ $\mathrm{PC}_{61} \mathrm{BM}$ blends were dissolved into $\mathrm{CB}$ to make the solutions of the D-A blends for spin-coating, respectively. Photovoltaic devices were tested under the illumination of AM1.5G, 100 $\mathrm{mW} \mathrm{cm}^{-2}$. The performance of the PSCs were strongly affected by the processing parameters, such as the choice of solvent, the blend ratio of the polymer to $\mathrm{PC}_{61} \mathrm{BM}$, and the additive effects. ${ }^{18}$ The photovoltaic effect of the two polymers were investigated under a variety of conditions. The ratio of polymer to $\mathrm{PC}_{61} \mathrm{BM}$ was adjusted from $2: 1,1: 1$ to $1: 2$ (by weight), and the optimized condition was $1: 1$ for both of them. Addition of 1,8-diiodooctane gave no improvement on PCEs. Thermal annealing process helps improving the PCE of PEBBDT but decreasing the performance for PEBTTZ. Figure 3 shows the current density versus voltage $(J-V)$ curves of the devices with optimum D-A ratio; the basic photovoltaic data are listed in Table 3. The device based on the PEBBDT:PC ${ }_{61} \mathrm{BM}$ blend exhibited a great $V_{\text {oc }}$ of $0.92 \mathrm{~V}$, a $J_{\mathrm{sc}}$ of $2.38 \mathrm{~mA} \mathrm{~cm}{ }^{-2}$, a FF of $39 \%$, delivering a PCE of $0.85 \%$. And the device using PEBTTZ: $\mathrm{PC}_{61} \mathrm{BM}$ blend exhibited a $V_{\text {oc }}$ value of $0.90 \mathrm{~V}$ and a larger $J_{\text {sc }}$ of $5.95 \mathrm{~mA} \mathrm{~cm}^{-2}$ with an improved PCE of $2.40 \%$. High $V_{\text {oc }}$ values $(\geq 0.90 \mathrm{~V})$ of both polymers were resulted from the deep HOMO level

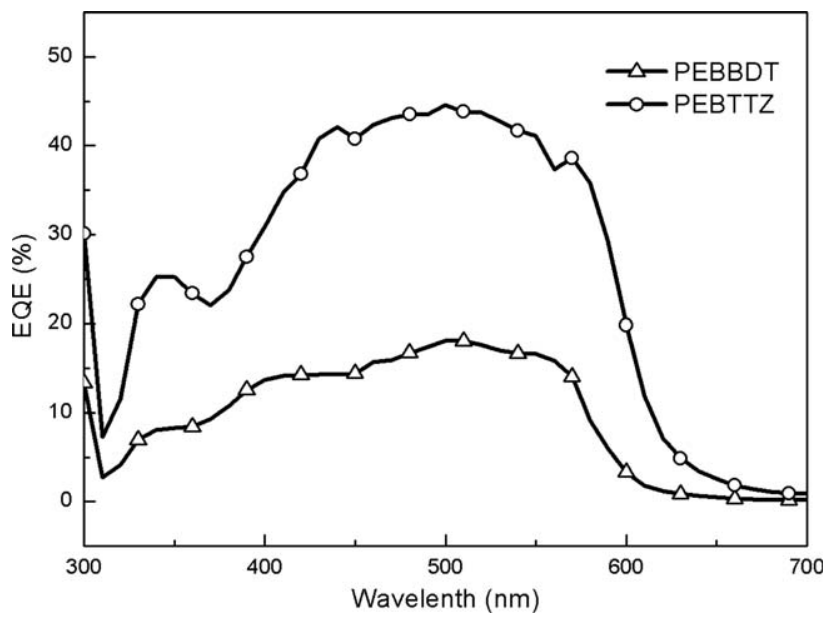

FIGURE 4 EQE curves of the PSCs based on polymers: $\mathrm{PC}_{61} \mathrm{BM}$ $(1: 1)$. 


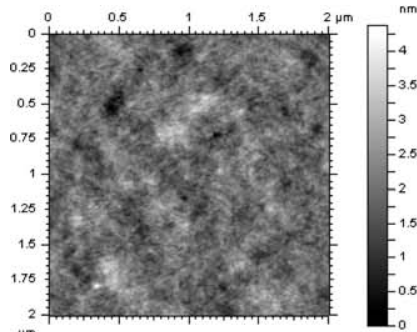

(a)

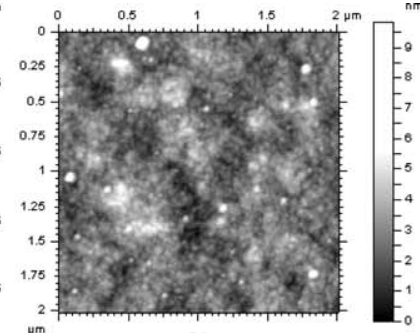

(b)

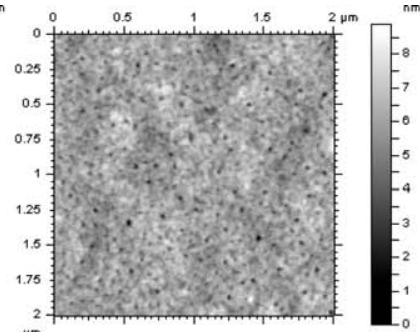

(c)

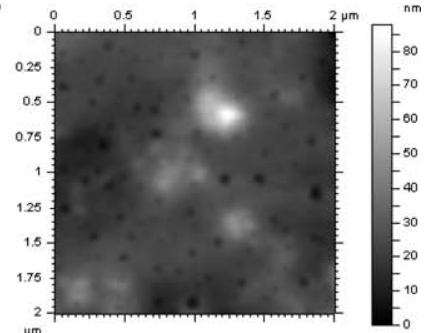

(d)

FIGURE 5 AFM height images of polymer:PC ${ }_{61} B M(1: 1)$ blend films: (a, b) PEBBDT, (c, d) PEBTTZ, (a, c) as-cast, and (b, d) annealed at $80^{\circ} \mathrm{C}$.

$(\leq-5.50 \mathrm{eV})$. Compared to PEBBDT, PEBTTZ showed higher $J_{\mathrm{sc}}$ value, which may be originated from the relatively lower band gap and stronger $\pi-\pi$ stacking interaction. Thermal treatment has great influence on PCE especially the $J_{\mathrm{sc}}$. Annealing the blend film at $80{ }^{\circ} \mathrm{C}$ for $10 \mathrm{~min}$, all the parameters of PEBBDT was increased and the $J_{\mathrm{sc}}$ increased from 1.51 to $2.38 \mathrm{~mA} \mathrm{~cm}^{-2}$. However, for PEBTTZ, the parameters of the device were decreased upon thermal annealing. This opposite results may be induced by different transformation of morphologies during the annealing process, which will be discussed later. The relatively low FF values of two polymers indicate unfavorable compatibility between donor and acceptor, which could be optimized by the spin-coating condition, active layer morphology, and device structure. ${ }^{19}$

EQE spectra were measured under illumination of monochromatic light (Fig. 4). It is observed that the EQE value of PEBTTZ is higher than that of PEBBDT in the whole spectra (325-600 $\mathrm{nm}$ ) and the maximum value reaches $43 \%$. It indicates that PEBTTZ has good photo response among the absorption range and PEBBDT is inefficient.

\section{Morphological Characterization}

To investigate the effect of nanoscale topography on the performance of PSC, AFM was employed to measure the surface morphology. ${ }^{20}$ The height images of the blends (polymer$\left.\mathrm{s}: \mathrm{PC}_{61} \mathrm{BM}=1: 1\right)$ prepared from $\mathrm{CB}$ solution are shown in Figure 5.

The unannealed blend film of PEBBDT exhibits an organized nanofibrillar structure with a root-mean-squared (rms) surface roughness of $0.44 \mathrm{~nm}$ [Fig. 5(a)]. After annealing at 80 ${ }^{\circ} \mathrm{C}$, the blend film appears small crystallite region [Fig. 5(b)], which is favorable for the charge transferring. Therefore, the $J_{\text {sc }}$ and PCE were increased as a result. As for PEBTTZ, the unannealed blend film exhibits a uniform and smooth surface formed by tightly packed small and regular unconnected grains [Fig. 5(c)]. ${ }^{21,22}$ This structure is destroyed upon the annealing process and the surface roughness is increased from 0.82 to $5.81 \mathrm{~nm}$ [Fig. 5(d)]. The coarsening of morphology reduces the diffusion and separation of excitons and charge transport, leading to lower $J_{\text {sc }}$ and FF. Thus, the ascast device of PEBTTZ shows higher properties. The morphologies of the two blends well support the photovoltaic performance (Fig. 3 and Table 3).

\section{CONCLUSIONS}

We have successfully synthesized two novel polymers PEBBDT and PEBTTZ by Pd-catalyzed Sonogashira coupling reaction. The polymers are characterized as ethynylenecontaining D-D- and D-A-type structures, respectively. The investigation of optical properties shows that PEBBDT and PEBTTZ have similar optical band gap with 2.08 and $2.04 \mathrm{eV}$ and HOMO level of -5.57 and $5.50 \mathrm{eV}$, respectively. Both copolymers were applied as electron-donating materials with $\mathrm{PC}_{61} \mathrm{BM}$ as acceptor in conventional $\mathrm{BHJ}$ photovoltaic devices. The PSC based on PEBBDT:PC ${ }_{61} \mathrm{BM}=1: 1(\mathrm{w} / \mathrm{w})$ reached a PCE of $0.85 \%$ with $J_{\mathrm{sc}}=2.38 \mathrm{~mA} \mathrm{~cm}{ }^{-2}, V_{\mathrm{oc}}=0.92 \mathrm{~V}$, and $\mathrm{FF}=39.0 \%$, and the PSC based on PEBTTZ: $\mathrm{PC}_{61} \mathrm{BM}=1: 1$ $(\mathrm{w} / \mathrm{w})$ reached a PCE of $2.40 \%$ with $J_{\mathrm{sc}}=5.95 \mathrm{~mA} \mathrm{~cm}^{-2}$, $V_{\text {oc }}=0.90 \mathrm{~V}$, and $\mathrm{FF}=45.0 \%$, under the illumination of AM1.5G, $100 \mathrm{~mW} \mathrm{~cm}^{-2}$. High $V_{\text {oc }}$ values of over $0.90 \mathrm{~V}$ were achieved for both polymers, which were attributed to the deep HOMO levels. Although two polymers possess similar band gaps and energy levels, the D-A-type polymer PEBTTZ exhibits even higher photovoltaic performance.

\section{ACKNOWLEDGMENTS}

This work was supported by National Natural Science Foundation of China (21202181, 51173199, 61107090), Ministry of Science and Technology of China (2010DFA52310), Chinese Academy of Sciences (KGCX2-YW-399+9-2), Department of Science and Technology of Shandong Province (2010GGC10345, ZR2012BQ021), and State Key Laboratory of Luminescent Materials and Devices (South China University of Technology).

\section{REFERENCES AND NOTES}

1 Y. J. Cheng, S. H. Yang, C. S. Hsu, Chem. Rev. 2009, 109, 5868-5923.

2 Y. F. Li, Acc. Chem. Res. 2012, 45, 723-733.

3 G. Dennler, M. C. Scharber, C. J. Brabec, Adv. Mater. 2009, $21,1323-1338$.

4 J. W. Chen, Y. Cao, Acc. Chem. Res. 2009, 42, 1709-1718.

5 H. Y. Chen, J. H. Hou, S. Q. Zhang, Y. Y. Liang, G. W. Yang, Y. Yang, L. P. Yu, Y. Wu, G. Li, Nat. Photonics 2009, 3, 649-653.

6 S. C. Price, A. C. Stuart, L. Yang, H. Zhou, W. You, J. Am. Chem. Soc. 2011, 133, 4625-4631. 
7 T.-Y. Chu, J. Lu, S. Beaupre, Y. Zhang, J. Pouliot, S. Wakim, J. Zhou, M. Leclerc, Z. Li, J. Ding, Y. Tao, J. Am. Chem. Soc. 2011, 133, 4250-4253.

8 Z. He, C. Zhong, S. Su, M. Xu, H. Wu, Y. Cao, Nat. Photonics 2012, 6, 591-595.

9 P. M. Beaujuge, J. M. J. Fréchet, J. Am. Chem. Soc. 2011, 133, 20009-20029.

10 C. Kitamura, S. Tanaka, Y. Yamashita, Chem. Mater. 1996, 8, 570-578.

11 U. H. F. Bunz, Macromol. Rapid Commun. 2009, 30, 772-805.

12 (a) R. S. Ashraf, M. Shahid, E. Klemm, M. Al-lbrahim, S. Sensfuss, Macromol. Rapid Commun. 2006, 27, 1454-1459; (b) C. Du, W. Li, C. Li, Z. Bo, J. Polym. Sci. Part A: Polym. Chem. 2013, 51, 383-393; (c) Y. Hou, Y. Chen, Q. Liu, M. Yang, X. Wan, S. Yin, A. Yu, Macromolecules 2008, 41, 3114-3119; (d) Y. P. Zou, Z. Tan, L. J. Huo, Y. F. Li, Polym. Adv. Technol. 2008, $19,865-871$.

13 J. Cremer, P. Bauerle, M. M. Wienk, R. A. J. Janssen, Chem. Mater. 2006, 18, 5832-5834.
14 S. P. Webster, J. R. Seckl, B. Walker, P. R. Ward, T. D. Pallin, H. J. Dyke, T. R. Perrior, PCT Intl WO/2009/074789 2009.

15 Q. Shi, H. Fan, Y. Liu, W. Hu, Y. Li, X. Zhan, Macromolecules 2011, 44, 9173-9179.

16 J. L. Bredas, R. Silbey, D. S. Boudreaux, R. R. Chance, J. Am. Chem. Soc. 1983, 105, 6555-6559.

17 B. C. Thompson, J. M. J. Fréchet, Angew. Chem., Int. Ed. 2008, 47, 58-77.

18 L.-M. Chen, Z. Hong, G. Li, Y. Yang, Adv. Mater. 2009, 21, 1434-1449.

19 J. Kim, M. H. Yun, G.-H. Kim, J. Y. Kim, C. Yang, Polym. Chem. 2012, 3, 3276-3281.

20 M. Campoy-Quiles, T. Ferenczi, T. Agostinelli, P. G. Etchegoin, Y. Kim, T. D. Anthopoulos, P. N. Stavrinou, D. D. C. Bradley, J. Nelson, Nat. Mater. 2008, 7, 158-164.

21 E. Zhou, J. Cong, K. Hashimoto, K. Tajima, Energy Environ. Sci., 2012, 5, 9756-9759.

22 M.-S. Su, C.-Y. Kuo, M.-C. Yuan, U.-S. Jeng, C.-J. Su, K.-H. Wei, Adv. Mater. 2011, 23, 3315-3319. 